\title{
新年のごあいさつ
}

紙パルプ技術協会 理事長 池田 健 郎

\section{New Year's Speech}

\author{
Kenro Ikeda \\ President ; JAPAN TAPPI
}

会員の皆様，あけましておめでとうごさいます。 平成 3 年の年頭にあたり,一言ごあいさつ申し上 げます。

昨年は, 政治的には米ソ協調，東西ドイッの統 合, イラクのクエート侵攻など激動の年でありま した。社会面では，眇境問題，特に地球規模での 環境問題が大きくクロースアップしてまいりまし て, オソン層の破壤, 酸性雨, 地球の温暖化など の対策を探る国際会議が相次いで開催され, 連日 のようにマスメディアを通して報しられました。

経済面では，我が国の経済は此較的順調に推移 し, '90 年度は企業の壳り上げ, 利益とも 4 年連続 の最高益更新となりまして、戦後最長であった 「いさなき景気」に匹敵する好況ふりで推移しま した。しかし後半には，株安，金利高，原油高と 企業収益謤境にはマイナス要因が相次いで浮上し てまいり，先行きの見通しに注意信号が点滅し始 めました。

これらの経済動向は業種別で差がありまして, 例之ば, 建設, 重承, 産業機械, 造船など加工組 立産業は好況に推移したのに比して, 電力, 鉄 銅，紙パルプなどの素材・エネルキーは低迷して おりまして，明暗がはっきりしてまいりました。

さて，本年の経済につきましては，経済の先行 きに確信を持って見通すことは困難であります。 経斉動向を左右する因子をみてみますと，(1)中東 紛争の今後, (2)アメリカ経清の動向, 財政再建の 進展，(3)国内の信用膨張下での土地問題の行方な どかどのようになるかさらに一昨年面頃からすで に変化が芽生え，我が国経济の体内に疲労現象が 出始めておりまして, 外部変化への抵抗力を失い つつある矢先であり，正に転換期を迎えていると 考えております。従って，本年は景気論争が一転 して，“いつまで好況が持続するか”より“今後の 景気の底”をどのように読むかを考える時期では

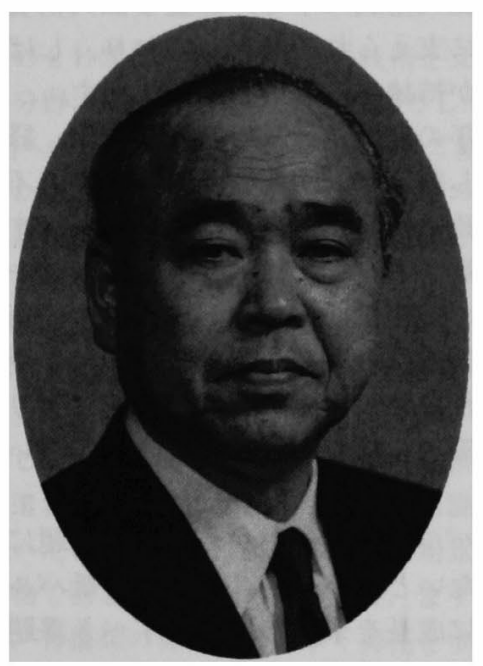

ないかと考える次第であります。

次に紙パルプ産業の展望に触れてみたいと思い ます。我が国の 1989 年度紙の生産量は 26,809 千 $\mathrm{t}$ ，消費量は 27,444 千 $\mathrm{t}$ でともに世界第 2 位であ ク, 一人当りの消費量はアメリカ $303.9 \mathrm{~kg}$, ス ウェーデン $229.1 \mathrm{~kg}$ に次いで $222.7 \mathrm{~kg}$ と 3 位ま で躍進してまいりました。

営業利益は '82 年以降, 紙パルプ産業は製造業 の平均を上回り，金利低下などによる金融収支の 改善も進み, '86 年以降は経常利益でも製造業平均 を淩駕してきましたが，昨年中頃から增益テンポ は逆転して減益に転し，本年 3 月期はさらに厳し さが予想されます。

紙パルプ産業の業績低迷の要因は株安, 金利高, 原油高などの収益環境のマイナス要因に加えて， 製品価格の急速なタウン, 市況の低迷, 新增設 ラッシュによる需給のアンバランスなどによりま

して，その回復に時間がかかるものと思われます。 紙の需給動向は, 一般概況としましては, '90 年 
度は四半期毎に見た対前年伸び率は生産・払出し とも期を追って鈍化傾向にありまして, 特に非塗 工印刷用紙は不調で昨年実績を下回る結果となっ ております。その中で染工紙は堅調な個人消費を バックに広告・宣伝関連需要の好調に支えられ底 堅い需要がありました。また大幅な伸びを示して おりました情報用紙は需要がほほ一巡し, 安定成 長に入ったためか，伸びは低調に終始しました。

一方, 板紙は生産・払出し共に比較的順調な伸 びを示しまして秖と明暗を分ける結果となりまし た。板紙の需要は記録的に持続する内需を中心と した景気拡大基調の中で, 旺盛な個人消费・設備 投資などに支えられて增大しており，しばらくは この傾向が持続するものと思われます。

さて本年の需給見通しでありますが, 経凪の先 行き見通し難, 個人消動向の鈍化への不安, 巳 らに国際政治情势から来る日本経済に対する役割 分担の要請などを考えますと, 経済変動から来る 需給事情の変化は悪化が心配されます。新設マシ ンの稼動開始にともなう需給の楥和は必至である と予想されますが, 生産調整の持続により,これ 以上の採算悪化はなんとしても防止したいもので あります。

次に紙パルプ産業がかかえている課題について 触れてみたいと思います。我が国の紙パルプ産業 が安定的に成長を果すのに解消すへき課題としま しては，(1)原料問題の克服：新規ソースの開拓や 海外造林, (2)古紙利用の拡大: リサイクル 55 計 画の推進と回収システム・利用技術の確立，(3)環 境問題への挑戦：地球瓄境への対応とタイオキシ ン, AOX 对策, (4) 製品開発と市場開発の重要 性: 紙需要の潜在力の発現, (5)技術開発の必要 性：問題解消と競争力確保などを考えております か，これらは昨年度の技術協会の年次大会で述へ， 本誌に記载されていますので，詳細は割愛させて いただきます。

それでは技術協会の諸活動について若千触れて みたいと思います。時系列的に記しますと，昨年 5 月には，国際技術交流の一環として，第 9 回日 加豪技術交流会議 “1990 Pan Pacific Joint Conference”がニュージーランドで開催され, 我が国 から研究発表 5 件の発表者を含めて 15 名が参加 しました。アメリカの TAPPI から参加の申し出
があり，次回から 4 力国で順次開催することにな る可能性が高まっております。次回は来年'92 年 に我が国で開催することになっており，その準備 が開始されておりますが, 皆様の積極的な参加を お願いする次第であります。

第 57 回紙パルプ研究発表会を 6 月に, 第 14 回 紙パルプ計装発表会と計装ショーを10月に,いず れも東京で開催しました。両発表会とも定員をこ える参加申し込みがありまして，参加をお断わり する程の盛況でございました。本年も両発表会は ほほ同し時期に開催する計画でごさいます。今後 もこのような発表会の内容を充実させ魅力あるも のにしまして, 会員の皆様の技術力向上に役立て たいと考えております。

平成 2 年度の年次大会は, 本年は会場を東京に 移して，東京ならではの大会にしようとして，サ プタイトルを“21 世紀に向って紙パルプ技術の未 来を探る”とつけ，エポックメーキンクになるよ うな大会にしようと企画しましたところ，970名 を越える過去最大を記録し, 極めて盛大に行うこ とかできました。特別講演は東海大学開発技術研 究所教授 唐津一先生にお願いして、「21 世紀 に向かっての技術の課題と展望」の題名で講演し ていただきました。先生は産業界で活躍された関 係もあって極めて示啐に富んだお話をしていただ き,時間の経過するのも忘れる位でした。さらに本 大会には海外から多くの講演者がありまして海外 の技術開発を直接拝聴できる幸運に恵まれまし た。また一般講演，製品展示会社による新製品・ 新技術の紹介も質的に高く，ご参加の皆様に满足 していただけたものと思っております。

本年の年次大会は熊本市に移して, 従来の操業 経験を中心に勉強することになります。十条製紙 林にお世話になることになっておりますが，何卒 よろしくお願い申し上げます。

その他にも各種の講演会・シンポシュウム等の 共催や協責を予定しておりますので，積極的なご 参加をお願い致します。

最後になりましたが，当紙パルプ技術協会の発 展のため, 皆様方の一層のご支援をお願い致しま すとともに，会員の皆様方の益々のご発展をお祈 クし，新年のご挨拶と致します。 